Papers and Proceedings of the Royal Society of Tasmania, Volume 117, 1983.

(ms. received 4.6 .1982 )

TWO STRIGEOID TREMATODES, APATEMON (AFATEMOIN) GRACILIS (RUDOLPHI, 1819) AND DIPLOSTOMUM (D LICHORCHIS) GALAXIAE N.SP., WHICH ENCYST IN THE FRESHWATER FISH GALAXIAS AURATUS JOHNSTON IN LAKE CRESCENT, TASMANIA.

by S.J. Smith and J.L. Hickman

The Friends' School, Hobart and Department of Zoology, University of Tasmania

(with nine tables, six text-figures and one plate)

ABSTRACT

SMITH, S.J. \& HICKMAN, J.L., 1983 (31 viii): Two strigeoid trematodes, Apatemon (Apatemon) gracilis (Rudolphi, 1819) and Diplostomum (Dolichorchis) galaxiae n.sp., which encyst in the freshwater fish Galaxias auratus Johnston in Lake Crescent, Tasmania. Pap. Proc. R. Soc. Tasm., 117: 21-39. https://doi.org/10.26749/rstpp.117.21 ISSN 0080-4703. The Friends' School, Hobart andDepartment of Zoology, University of Tasmania, Hobart, Tasmania.

The metacercaria and adult of Apatemon (Apatemon) gracilis (Rudolphi) and Diplostomm (Dolichorchis) galaxiae n.sp. are described and figured. Metacercarial cysts of these species occur in different parts of the endemic fish Calaxias auratus: A. gracilis in the body cavity, orbit and vitreous humour, and D. galaxiae n.sp. visible as black spots ('black-spot disease') in the musculature of the body and head. A gracilis which has not previously been recorded from Australia occurs in the black duck, Anas superciliosa, while D. galaxiae n.sp. infects the white-faced heron, Ardea novaehollancilae. The domestic duck, Anas platyrhynchos, is much more susceptible to experimental infection by Apatemon gracilis than by $D$. galaxiae n.sp. Both flukes inhabit the upper small intestine of their bird hosts. The reproductive system of D. galaxiae n.sp. is amphitypic. D. galaxiae n.sp. most closely resembles D. heronei Srivastava, 1954 and D. Ketupanensis Vidyarthi, 1937; a key to species in the sub-genus Dolichorchis is given.

\title{
INTRODUCTION
}

Galaxias auratus Johnston, a small freshwater fish endemic to Lakes Sorell and Crescent in central Tasmania has been found to suffer from black-spot (or black-grub) disease (plate 1). This disease, caused by trematode cysts, has been reported from many species of freshwater fish of various taxonomic groups around the world (Singh 1956; Ganapati \& Rao 1962; Hoffman 1967; and Berra \& Au 1978), but has not previously been recorded in Austra1ia. Investigation revealed that the black spots in G. auratus were cysts of Diplostomum (Dolichorchis) galaxiae n.sp., and that the fish also harboured cysts of Apatemon (Apatemon) gracilis (Rudolphi, 1819). A gracilis encysts in the body cavity, orbit and vitreous humour; and D. galaxiae n.sp. encysts in the musculature throughout the body and head.

In the laboratory gravid adults of both species were recovered from domestic ducklings, Anas platyrhynchos L., which had been fed with cysts from naturally infected Galaxias auratus from Lake Crescent. A black duck, Anas superciliosa Gmelin, killed at Calverts Lagoon southeast of Hobart, Tasmania, was found to be infected with adult flukes conforming to the description of Apatemon gracilis. Two white-faced herons, Ardea novaehollandiae Latham, killed while feeding on Galaxias auratus at Lake Crescent, were each found to harbour hundreds of flukes identical to adults of Diplostomum galaxiae n.sp. taken from experimentally infected ducklings.

Apatemon (Australapatemon) intermedius (Johnston, 1904) Dubois, 1937 is the only member of this genus previously recorded in Australia. In South Australia, it encysts in freshwater leeches, and matures in the black swan (Johnston \& Angel 1951; Dubois \& Pearson 1965). Six species of Diplostomum have previously been recorded in Australia: D. (Adenodiplostomum) triangulare (Johnston, 1904) Dubois \& Pearson, 1967; D. (Diplostomun) spathacewn murrayense (Johnston \& Cleland, 1938), adult described by Johnston \& Angel (1941); D. (Diplostomum) amygalalum Dubois \& Pearson, 1965; D. (Dolichorchis) auriculosum 


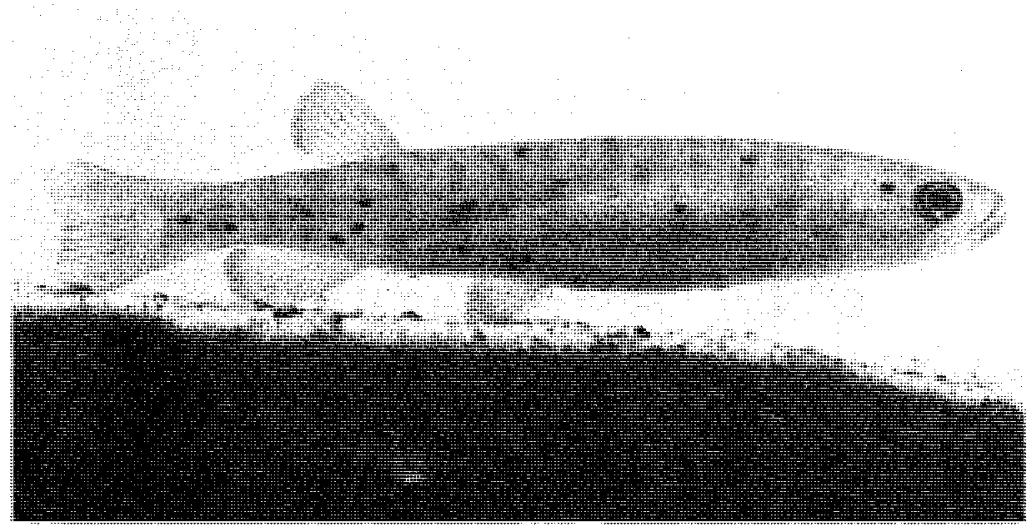

PLATE 1 - Golden galaxiid, Galaxias curatus, from lake Crescent. Trematode cysts (Diplostomum galaxiae n.sp.) are visible as dense black spots in mus culature of the body and head. Photo: J. Lim, $x 3 / 2$.

\section{$30 \mathrm{~mm}$}

Dubois \& Pearson, 1967; D. (Diplostomum) pamulum Dubois \& Angel, 1972; and D. (TyZodelphys) podicipinum podicipinum Kozicka \& Niewiadomska, 1960, recorded in Australia by Dubois \& Ange1 (1972). These Diplostomm species infest piscivorous birds of the families Alcedinidae, Anhingidae, Ardeidae and Laridae.

\section{MATERIALS AND METHODS}

Galaxias auratus were collected at lake Crescent on $2 / 4 / 78$ and $26 / 6 / 78$, and brought back to the laboratory where they were maintained in a freshwater aquarium unti 1 required for autopsy. Cysts, on removal from the host, were placed in Hank's balanced salt solution (Hank's BSS). Domestic ducklings, raised under controlled conditions, were fed metacercarial cysts in gelatin capsules (Parke Davis and Co., Empty Gelatin Capsules No.4), and dissected after intervals from 1 hour to 30 days 19 hours in the case of those fed cysts of Diplostomm gataxiae n.sp. and after 18 hours to 30 days 19 hours for those fed cysts of Apatemon gracilis. An abbreviated method of referring to time, viz. 30,19 days for 30 days 19 hours is used throughout this paper. Two black ducks were shot at Calverts Lagoon on $27 / 4 / 78$ and two white-faced herons were killed at Lake Crescent on $27 / 6 / 79 .$. The domestic ducklings were dissected immediately they were killed. The other birds were held at $5{ }^{\circ} \mathrm{C}$ pending the autopsy which was undertaken within 24 hours. For the purpose of recording the location of trematodes in the put of birds the small intestine was divided into ten equal lengths, numbered (from the pylorus) S1 to $\$ 10$. Trematodes were removed, rinsed in Hank's BSS, and fixed in boiling $10 \%$ phosphate buffered formol saline.

Metacercariae were excysted in vitro using techniques similar to those used by Blair (1976) to excyst Apatemon gracizis, and by Mitchell et al. (1978) to excyst Cotyzurus erraticus. Cysts were exposed to a sequence of solutions in test tubes held in an intermittently-shaking water-bath at $41 \pm 11^{\circ} \mathrm{C}$ :

(i) $10 \mathrm{~m} 1$ of $2 \%$ pepsin (B.D.H.) in Hank's BSS, adjusted to pH 2.0 with $0.1 \mathrm{~N} \mathrm{HC1,} \mathrm{for} 10$ minutes;

(ii) $10 \mathrm{ml}$ of $0.2 \mathrm{M}$ sodium dithionite in Hank's BSS, for 15 minutes;

(iii) $10 \mathrm{~m}$ of $0.5 \%$ pancreatin (Viokase) and $0.2 \%$ sodium taurocholate (B.D.H.) in Hank's BSS gassed to pH 7.4 with $5 \% \mathrm{CO}_{2}$ in air, for 60 minutes, or until excystment.

Between successive treatments cysts were transferred to crystal dishes under a dissecting microscope and quickly washed twice in Hank's BSS. Glassware and saline were kept at about $41^{\circ} \mathrm{C}$. 


\section{S.J. Smith and J.L. Hickman}

In the following descriptions, unless otherwise stated, all measurements are given in microns (mean first, followed by size range in parenthesis). Drawings were made with the aid of a canera lucida.

Superfamily STRIGEOIDAE Railliet

Family STRIGEIDAE Railliet

Apatemon (Apatemon) gracitis (Rudolphi, 1819) Szidat, 1928

$$
\text { 1. ADULT (fig. 1) }
$$

The dimensions of ovigerous adults from a naturally infected black duck and experimentally infected laboratory dukciings, are presented in table 1 .

\section{Description}

Body strongly flexed dorsally at junction of fore and hindbody. Cup-shaped forebody separated by deep constriction from larger, arcuate hindbody. Oral sucker round, mouth subterminal, pre-pharynx absent; oesophagus short, bifurcating immediately posterior to smal1 round pharynx; caeca narrows (orange-brown contents conspicuous in 1 ive worms from black duck), extending to posterior of hindbody. Ventral sucker more or less round. Discrete ovoid gland at base of foliaceous holdfast organ. paranephridial canals large, conspicuous throughout body; excretory pore terminal. Reproductive organs confined to hindbody. Testes lobed, contiguous, tandem, posterior to ovary. Seminal vesicle coils between posterior testis and genital cone, narrowing distally, joining terminal part of uterus to form hermaphrodite duct. Ovary oval, contiguous to anterior testis. Oviduct passes dorsally, from posterodorsal border of ovary, giving rise to Laurer's canal, which opens dorsal to anterior testis. Ciliated ootype overlies dorsal lobe of anterior testis. Vitellaria confined to hindbody, ventral. and overlapping gonads. Vitelline reservoir dorsal, inter-testicular. Uterus loops anteroventrally from ootype, extending along ventral border of testes, joining seminal vesicle posterior to posterior testis. Hermaphrodite duct opens through protrusible genital cone, within subterminal-dorsal copulatory bursa. Uterus contains up to 14 eggs.

Hosts

Anas pzatyrhynchos L. (experimental), A. superciziosa Gmelin.

Geographical location

Lake Crescent (fish intermediate host); Calverts Lagoon (black duck).

Date of collection

Fish 2/4/78, 26/6/78 (col1. R. White, R.B. Mawbey); black duck 27/4/78 (co11.

R.B. Mawbey, S.J. Smith).

Habitat

Upper small intestine.

\section{Material}

Tasmanian Museum and Art Gallery: adults from black duck, Calverts Lagoon, K887; adults from laboratory duckling K888; excysted metacercariae $\mathrm{K} 889$.

\section{Relationships}

Adults recovered from a naturally infected black duck and experimentially infected laboratory ducklings fell within the range of previous descriptions of Apatemon (Apatemon) gracizis (Dubois 1951, Beverley-Burton 1961, Ricci \& Carrescia 1961, and Vojtek 1964). This species is noted for its morphological variability and Dubois (1953) suggested that it be divided into ten sub-species. Beverley-Burton (1961), however, observed that specimens taken from the same host can be assigned to several of these sub-species, and hence considered it preferable to regard this cosmopolitan species with a wide host range, as polytypic, rather than as a collection of sub-species.

A. (Apatemon) gracizis and A. (Austratapatemon) minor Yamaguti, 1933, have frequent ly been considered conspecific (Dubois 1968), and it is often impossible to determine which species is referred to when $A$. gracizis is reported, unless life-history studies have been 
Two Strigeoid Trematodes in Gazaxias caratus in Tasmania.
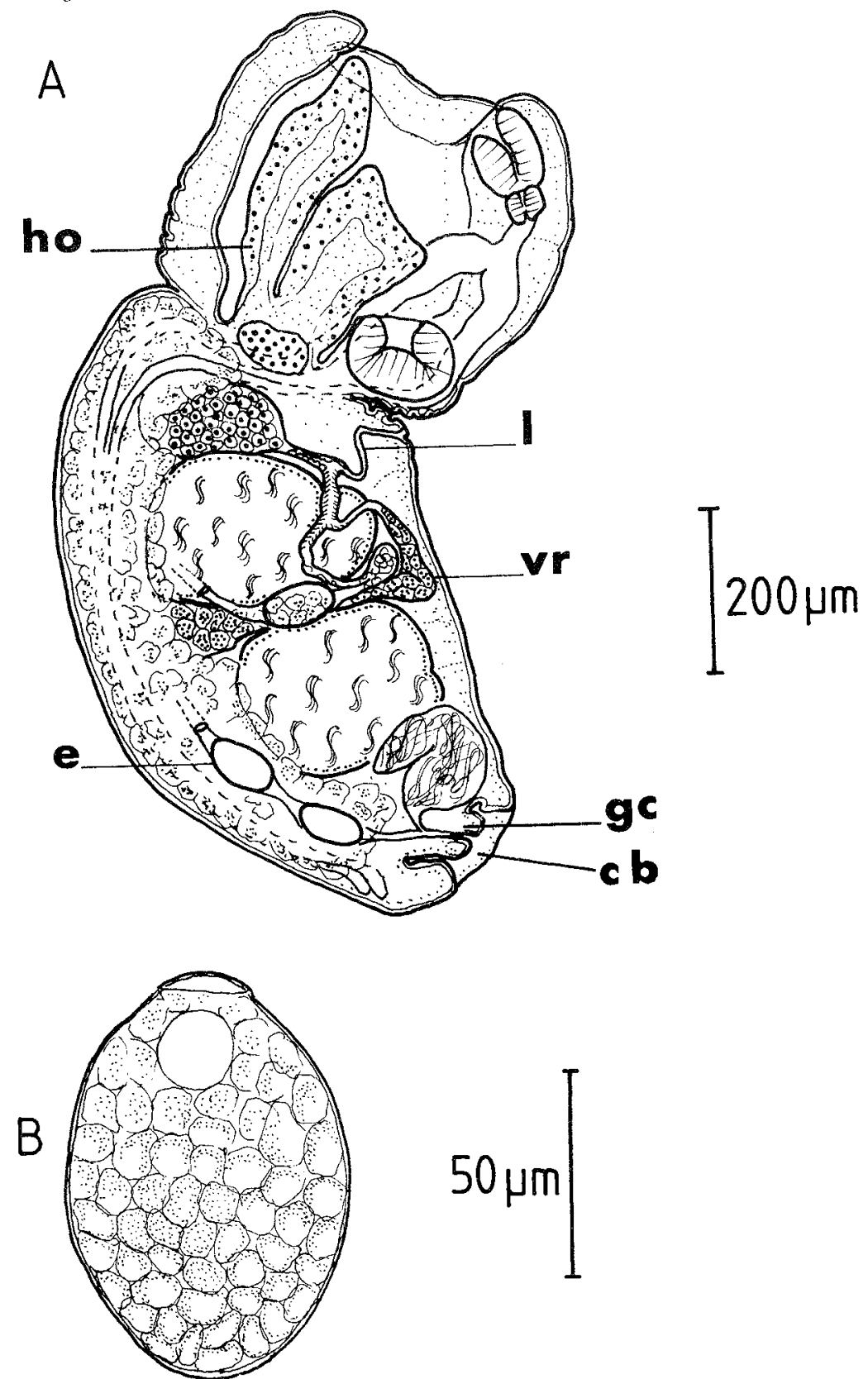

FIG. 1 - Apatemon gracilis. A: gravid adult after 4,21 days in experimentally infected duckling; B: egg deposited in duckling's intestine. (cb: copulatory bursa, e: egg, ge: genital cone, ho: holdfast organ, 1: Laurer's canal, vr: vitelline reservoir).

made. The former species utilizes fish as intermediate hosts and the latter, leeches (Blaix 1976). The present material evidently belongs to the former species. 
DIMENSIONS OF AFATEMON GRACILIS.

(a) metacercariae, excysted in vitro after 2 hours at $41^{\circ} \mathrm{C}$; (b), (c) and (d) adults recovered from experimentally infected ducklings after different periods of infection; and (e) adults from a naturally infected black duck.

Infection period (days)

Body 1ength

Forebody:depth length (FBL) width

Hindbody: depth$$
\text { width }
$$

Oral sucker. depth

$$
\text { length }
$$

ventral sucker:depth

$$
\text { r: depth }
$$

width

Pharynx:depth

$$
\begin{aligned}
& \text { length } \\
& \text { width }
\end{aligned}
$$

Holdfast organ: depth

$$
\text { length }
$$

Ovary: depth

$$
\text { (a) (b) }
$$$$
n=4
$$

(550-665)

$416(393-469)$

$144(-)$

$129(125-133)$

$$
\text { length }
$$

Anterior testis:depth

Posterior testis:depth : depth

O.S. $(1+w) /$ V.S. $(1+w)$

$\mathrm{FBL} / \mathrm{HBL}$

Eggs in uterus
$264(255-274)$

$174(166-197)$

$72(68-76)$

$78(76-80)$

$80(76-84)$

$91(87-95)$

$90(84-99)$

$95-$

$34=$

$32(30-34)$

$52(30-34)$

$55(49-61)$
$43(34-46)$

46

$957(847-1028)$

$355(331-391)$

$429(348-499)$

$467(433-502)$

$312(304-319)$

$346(342-350)$

$87(84-91)$

$87(84-91)$

$94(87-99)$

$129(114-141)$

$129(114-141)$

$120(106-133)$
$108(99-118)$

$108(99-118)$

$60(53-65)$

$44(42-46)$
$76(53-99)$

$68(65-72)$

$-$

$-$

0.85

2.39

0.82
3,19

(c)

4,21

(d)

8,1
$n=5$

(e)

$\mathrm{n}=3$

$335(1225-1452)$

$397(369-437)$

$544(499-590)$

$1182(1074-1300)$

$360(350-380)$

423 (393-469)

$1542(1315-1845)$

$510(469-529)$

$402(369-452)$

$791(650-907)$

$103(95-110)$

$103(95-114)$

$146(122-167)$

$127(122-137)$

$64(61-72)$

$57(49-61)$

81 (61-95)

$63(46-76)$

123 (103-144)

$89(84-95)$

$208(175-266)$

$158(114-220)$

$244(213-281)$

$234(220-255)$

0.75

0.69
$354(296-380) \quad 479(423-514)$

$759(680-832) \quad 912(786-1104)$

$85(76-91) \quad 86(76-95)$

$95(84-114)$

$144(129-156)$

$129(122-133)$

$64(53-68)$

$62(57-65)$

$84(76-95)$

$43(34-53)$

-

$-$

$108(99-118)$

$139(114-156)$

$155(137-167)$

$34 \quad-$

46

$92(84-106)$

$65(53-72)$

$143(122-175)$

$81(72-125)$

$274(217-346)$

$252(213-304)$

$275(171-388)$

$282(163-418)$

0.63 
Biology

Five out of seven ducklings fed cysts of A. gracilis from Galacias auratus were infected, with from 2 to 37 flukes. The percentage of metacercariae recovered as adults varied from 8 to 93 , and the maximum longevity recorded was 8,1 days. Adults were concentrated in S4 after 0.18 days, S2 after 3,19 days, S3 after 4,21 days, and S2 after 8,1 days. A black duck killed at Calverts Lagoon contained 27 adult A. gracilis, concentrated in S2. The distribution of adults in naturally and experimentally infected hosts is shown in figure 2.

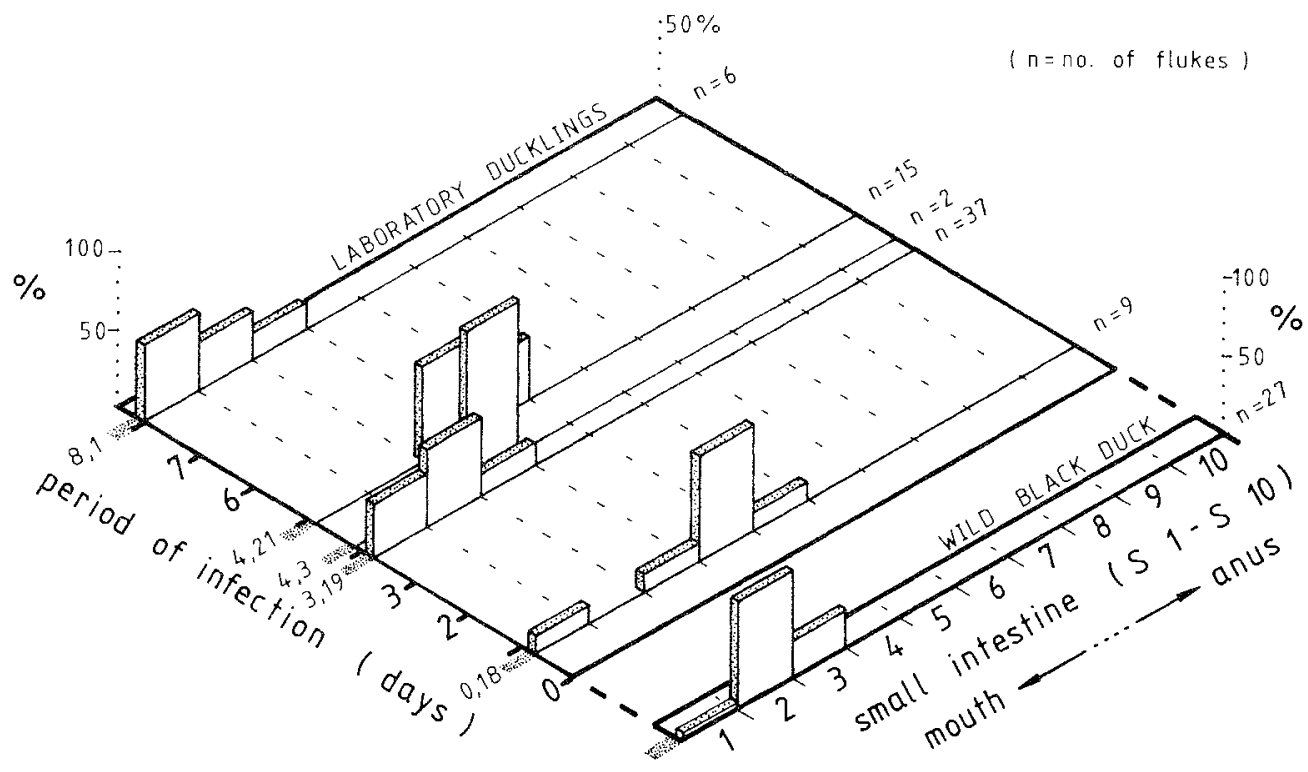

FIG. 2 - Apatemon gracilis. Distribution in the digestive tracts of a wild black duck, and laboratory ducklings. $(n=$ number of flukes $)$

Excysted metacercariae are very immature and genital primordia barely discernible. After 0,18 days in a laboratory duckling little growth or development had occurred; however, growth proceeded rapidly over the next few days. As the reproductive organs deve1oped, the hindbody grew from being a stumpy appendage to being larger than the forebody (fig. 3). After 3,19 days the FBL/HBL ratio had decreased from 2.39 for excysted metacercariae, to 0.83. At this stage the adults were mature and producing eggs. The hindbody continued to grow after egg production had commenced and after 8,1 days the FBL/HBL ratio was 0.66 . The number of uterine eggs was not directly related to the age of ovigerous adults (table 2). A maximum of 14 eggs was found in flukes after 4,3 and 4,21 days; however, after 8,1 days the maximum number of eggs in any fluke was only five. The naximum number of eggs found in flukes infecting the black duck was seven.

$$
\text { 2. } \operatorname{EGG}(\mathrm{fig} \cdot 1)
$$

The broadly oval egg is operculate and densely packed with granular vitelline cel1s. Colourless when formed, the egg-shell is tanned golden as it passes through the uterus. A clear spherical body, about $19 \mu \mathrm{m}$ diameter, underlies the operculum. The dimensions of live and fixed eggs in flukes from laboratory ducklings and fixed eggs in flukes from a wild black duck, are shown in table 3 . There was 1ittle difference in the size of fixed eggs from different hosts, however, fixed eggs were smaller than live eggs. 
FIG. 3 - Apatemon gracizis. A: metacercarial cyst from Galaxias auratus: B: excysted metacer. cariae after 2 hours at $41^{\circ} \mathrm{C} ; \mathrm{C}$ : gravic adults after 8,1 days in laboratory duck1ing - forebody of each adult adhering to an intestinal villus from host ( $B$ and $C$ drawn to same scale).
B
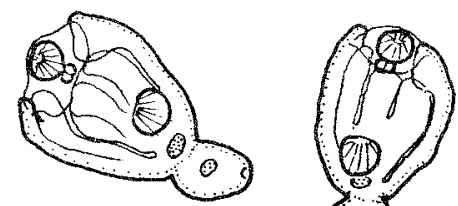

$8)$

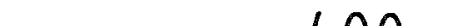

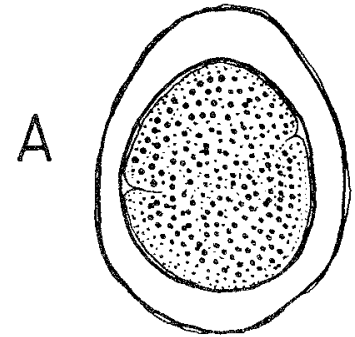

$\overparen{400 \mu \mathrm{m}}$

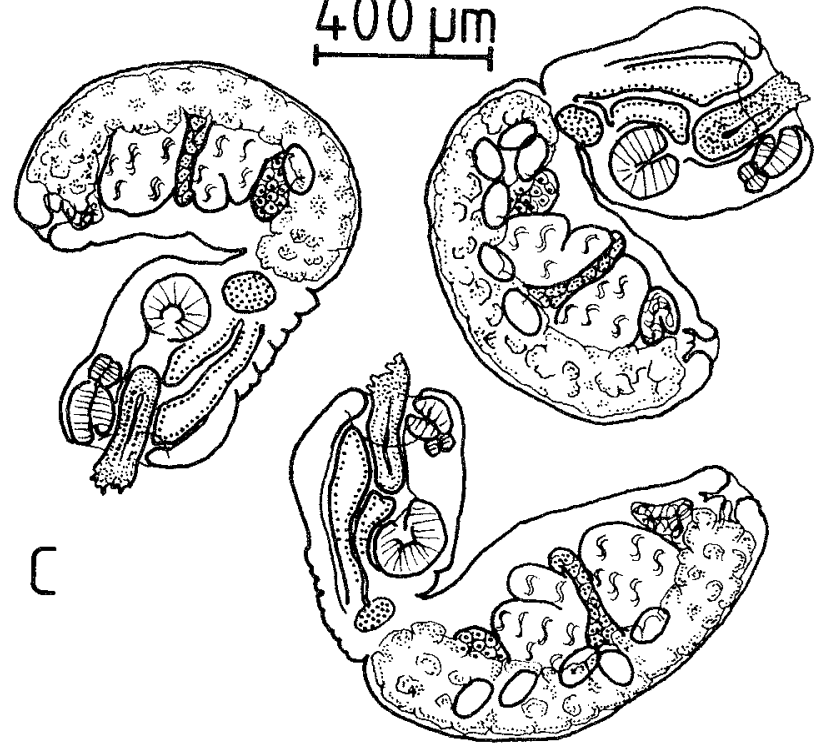

TABLE 2

THE NUMBER OF UTERINE EGGS IN ADULT APATEMON GRACILIS.

(a) from experimentally infected ducklings, and (b) from wild black duck.

Infection
period (days
(a) 3,19
4,3
4,21
8,1
(b) -

$\begin{array}{cr}\begin{array}{c}\text { Number } \\ \text { of } \\ \text { flukes }\end{array} & \text { Numbe } \\ & \text { Mean } \\ 30 & 0.5 \\ 2 & 11.0 \\ 11 & 3.5 \\ 5 & 2.8 \\ 11 & 2.0\end{array}$

Range

$(0-14)$

3.5
2.8

$(1-5)$

$(0-7)$ 
TABLE 3

DIMENSIONS OF EGGS OF APATEMON GRACILTS.

$\begin{array}{lll}\text { Host Nive/ } & \text { Number } & \text { Length Width }\end{array}$

$\begin{array}{lllllll}\text { Duckling } 1 & \text { live } & 6 & 103(95-106) & 71(68-72) \\ \text { Duckling 1 } & \text { fixed } & 6 & 99(95-103) & 63(61-68) \\ \text { Duckling 2 } & \text { fixed } & 9 & 99(95-106) & 61(57-67) \\ \text { Black duck } & \text { fixed } & 6 & 97(87-103) & 59(53-68)\end{array}$

\section{METACERCARIA}

Metacercarial cyst (fig. 3)

The thick-walled, white, oval to pyriform cyst, most frequently occurs in the body cavity of Gataxias auratus, particularly in connective tissue adjacent to the intestine. It is also frequently associated with the eye, either in the vitreous humour, or just outside the eyebal1, near the optic nerve. The cyst sometimes occurs between the peritoneum and muscle. Ten out of fourteen fish collected in June 1978 and June 1979, from the Clyde River where it enters Lake Crescent, were infected with Apatemon gracilis. The average number of cysts per infected fish was 5.5 (1-17) and the average size of the fish was 6.4 (4.8-9.9) cm. Eighty percent of these cysts were in or next to the body cavity, $18 \%$ were behind the eyeball next to the optic nerve and $2 \%$ were in the vitreous humour. The resilient cyst wall is translucent and homogenous, varying in thickness up to about $220 \mu \mathrm{m}$. A thin outer membrane, presumably of host origin, sometimes connects adjacent cysts. The densely packed contents of the cyst are opaque. Dimensions of ten cysts from the body cavity and two cysts from the vitreous humour of the eye, are shown in table 4 . There is no marked difference in size or morphology of the cysts from different locations in the fish host.

TABLE 4

CYSTS OF APATEMON GRACILIS FROM DIFFERENT FISH HOSTS.

Dimensions of live metacercarial cysts, dissected from naturally infected Gazacias curatus; from the brook stickleback, Eucalia inconstans, in North Dakota, U.S.A. (Hoffman 1959); and from the rainbow trout Salmo gairdneri, in Scotland (Blair 1976).

Host fish

\section{Number of} cysts

10

G. auratus (body)

G. auratus (eye)

E. inconstans

S. gairanemi

\section{External dimensions}

Width

$\begin{array}{ll}886(816-968) & 718(650-756) \\ 877(847-907) & 665(650-680) \\ 1000 & 600\end{array}$

$605(542-660) \quad 396(356-426)$
Internal dimensions

Length

Width

$\begin{array}{ll}587(423-650) & 493(348-552) \\ 544(529-559) & 529(484-575) \\ 507 & 444 \\ 503(465-542) & 293(279-310)\end{array}$

Excysted metacercaria (fig. 3)

The dimensions of some excysted metacercariae are presented in table 1 . The forebody is cup-shaped and relatively larger than in the adult worm. The oral and ventral suckers, pharynx and holdfast organ are well-developed in the forebody, but genital prinordia are barely discernible in the rudimentary hindbody. Body fluids and 1ipid droplets move through large paranephridial canals, throughout the body of live worms. 
S.J. Smith and J.L. Hickman

Family DIPLOSTOMIDAE POirier

DIPLOSTOMLM (DOLICHORCHIS) GALAXIAE n.sp.

1. ADULT (fig. 4)

The description of the adult of this new Diplostomum species is based on gravid flukes recovered from experimentally infected laboratory ducklings and naturally infected white-faced herons. The species is named after the endemic Tasmanian fish, Galaxias auratus, which serves as its second intermediate host. Dimensions of the holotype and other ovigerous and non-ovigerous adults, from naturally infected white-faced herons, are shown in tables 5 and 6 .

\section{TABLE 5}

OVIGEROUS ADULTS OF DIPLOSTOMUM GALAXIAE n.sp.

Dimensions of the holotype and other ovigerous adults, of 'sinistral' and 'dextral' types, from the white-faced heron.

Sample size

Body length

Forebody: depth length (FBL) width

Hindbody: depth length (HBL) width

Oral sucker:depth length width

Ventral sucker:depth length

Pharynx: length width

Left lappet: length width

Right lappet: length width

Holdfast organ: depth length
width

Ovary: depth length width

Anterior testis:depth

$$
\text { length }
$$

Posterior testis:

left lobe depth

$$
\text { length }
$$$$
\text { width }
$$

right lobe depth length width

O.S. $(1+w) /$ V.S. $(1+w)$

FBL/HBL

Number of uterine eggs

$$
\begin{gathered}
\text { 'Sinistral' } \\
n=11
\end{gathered}
$$

\begin{tabular}{|c|c|c|}
\hline \multicolumn{2}{|c|}{$\begin{array}{c}\text { 'Dextra I' } \\
\mathrm{n}=14\end{array}$} & $\begin{array}{c}\text { Holotype } \\
n=1 \\
\text { ('sinistral') }\end{array}$ \\
\hline 1002 & $(832-1074)$ & 937 \\
\hline 141 & $(106- \pm 97)$ & - \\
\hline 517 & $(393-635)$ & 575 \\
\hline 369 & $(287-438)$ & 318 \\
\hline 266 & $(227-287)$ & - \\
\hline 467 & $(378-499)$ & 378 \\
\hline 296 & $(204-333)$ & 280 \\
\hline 64 & $(53-76)$ & - \\
\hline 64 & $(57-68)$ & 65 \\
\hline 71 & $(59-84)$ & 65 \\
\hline 53 & - & - \\
\hline 62 & $(57-65)$ & 53 \\
\hline 70 & $(61-80)$ & 70 \\
\hline 48 & $(46-49)$ & 46 \\
\hline 34 & - & 38 \\
\hline 81 & $(76-84)$ & 91 \\
\hline 36 & $(27-49)$ & 53 \\
\hline 81 & $(68-99)$ & 76 \\
\hline 40 & $(34-49)$ & 53 \\
\hline 72 & $(68-76)$ & - \\
\hline 154 & $(133-179)$ & 141 \\
\hline- & & 141 \\
\hline 95 & - & - \\
\hline 65 & $(42-84)$ & 61 \\
\hline 85 & $(65-106)$ & 91 \\
\hline 176 & $(141-194)$ & - \\
\hline 102 & $(78-144)$ & 84 \\
\hline 130 & $(84-198)$ & 125 \\
\hline 144 & $(122-167)$ & - \\
\hline 156 & $(110-213)$ & 1.18 \\
\hline 78 & $(61-95)$ & 103 \\
\hline 143 & $(125-167)$ & - \\
\hline 164 & $(110-213)$ & 133 \\
\hline 97 & $(68-125)$ & 87 \\
\hline & 1.02 & 1.06 \\
\hline & 1.11 & 1.52 \\
\hline & $14(1-11)$ & 2 \\
\hline
\end{tabular}
'Dextral'
$n=14$

$\begin{array}{rl}957 & (892-1058) \\ 133 & (121-166) \\ 549 & (484-665) \\ 342 & (302-401) \\ 269 & (242-302) \\ 437 & (348-499) \\ 289 & (272-302) \\ 49 & (46-43) \\ 65 & (57-76) \\ 63 & (61-67) \\ - & \\ 63 & (59-68) \\ 73 & (67-80) \\ 49 & (46-57) \\ 36 & (34-38) \\ 87 & (76-91) \\ 46 & (42-53) \\ 87 & (76-95) \\ 49 & (46-53) \\ 70 & (68-72) \\ 136 & (110-160) \\ 136 & (114-148) \\ - & \\ 68 & (61-76) \\ 90 & (80-95) \\ 163 & - \\ 91 & (80-114) \\ 121 & (87-141) \\ 137 & - \\ 141 & (114-198) \\ 98 & (76-114) \\ 123 & (110-133) \\ 158 & (114-205) \\ 96 & (80-110) \\ & 0.94 \\ 1 & 1.26 \\ \end{array}$




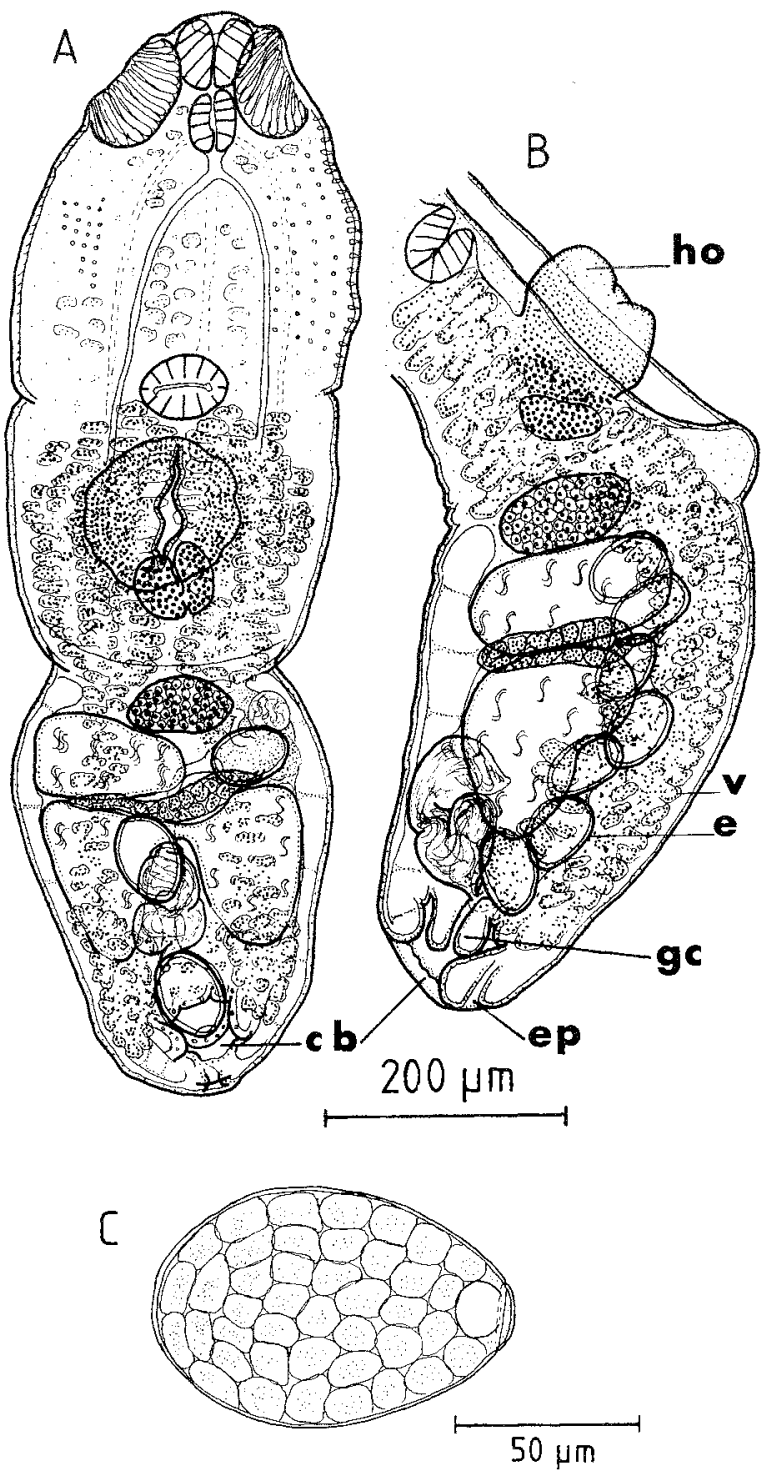

FIG. 4 - Diplostomum galaxiae n.sp. A: gravid adult, sinistral anterior testis, from whitefaced heron, dorsal view.

B : gravid adult, dextral anterior testis, from whitefaced heron, lateral view of hindbody. $\mathrm{C}$ : egg (cb: copulatory bursa, e: egg, ep: excretory pore, gc: genital cone, ho: holdfast organ, $v$ : vitellaria). 
Description

For ebody elongate, more or less rectangular, anterior body trilobate, posterior and posterolateral borders recurved ventrally. Hindbody conical, dorsally flexed, distinct from forebody. Tegumental spines on forebody diminishing in size posteriorly; hindbody aspinous. Tegumental gland cells distributed over anterior half of forebody. Oral sucker round, situated on prominent anterior protuberance bordered by well-developed crescentic lappets. Ventral sucker transversely oval; holdfast organ mobile, mushroom-shaped; both protrude into concavity of forebody. paranephridial canals anastomose throughout body. Excretory pore terminal. Mouth subterminal ventral; prepharynx absent; caeca narrow inconspicuous, diverging immediatcly posterior to small oval pharyn, then extending into hindbody. Bipartite gland at base of large, holdfast organ. Anterior testis dextral or sinistral, round to wedge-shaped. Posterior testis bilobed, elongate lobes joined by narrow anterodorsal commissure. Seminal vesicle voluminous coiled, lying between lobes of posterior testis, narrowing posteriorly to form ejaculatory duct, which joins uterus. Ovary oval sub-median, situated anteriorly in hindbody. Oviduct extends posterolaterally to ootype. ootypc surrounded by Mehlis' gland, opposite posterior half of anterior testis. Laurer's canal opens dorsally, at level of anterior testis. Seminal receptacle lateral to ovary. Vitellaria occupy posterior half of forebody, extending anteriorly to posterior border of ventral sucker; distribution in hindbody mainly ventral, lateral. Vitelline reservoir intertesticular. Uterus loops antero-ventrally, then extends posteriorly, ventral to seminal vesicle, uniting with ejaculatory duct. Short hermaphordite duct traverses small protrusible genital cone, within subterminal dorsal copulatory bursa. Up to 11 eggs in uterus.

The reproductive system of this species is amphitypic. In one wild host, a whitefaced heron, $58 \%$ of 92 mature adults (i.c. With vitellaria producing phenolic eggmshell precursors), had a sinistral anterior testis and the remaining $42 \%$ had a dextral anterior testis. The position of the testis is always clearly sinistral or dextral - there are no intermediates. No other distinct morphological differences could be found between the 'sinistral' and 'dextra1' types (tables 5 and 6). However, only $30^{\circ}$ of the 'sinistral' adults were ovigerous, compared with $54 \%$ of the 'dextral' adults; and there was a slight difference in the number of uterine eggs in each type: 1.9 (1-6) in 'sinistral' adults, and 3.1 (1-11) in 'dextral' adults. Fecundity of D. galaxiae n.sp. may be related to the position of the anterior testis.

Hosts

Anas platyrhynchos L. (experimental); Ardea novaeholzandiae Latham.

Geographical location

Lake Crescent.

Date of collection

Fish intermediate host $2 / 4 / 78,26 / 6 / 78$ (coll. R. White, R.B. Mawbey); white-faced herons 27/6/79 (coll. R.B. Nawbey, S.J. Smith).

\section{Habitat}

Upper small intestine.

Type material

Tasmanian Museum and Art Gallery: holotype K884, ringed (gravid adult); paratypes K885 (adults) and K886 (excysted metacercariae).

\section{Relationships}

This species has the characteristics of the subgenus Dolichorchis Dubois, 1961, i.e. asymmetrical anterior testis, elongated lobes of the posterior testis joined by a narrow dorsal commissure and the presence of a genital cone. Seven species of Diplostomum have previously been assigned to the subgenus Dolichorchis, however only one of these, Diplostomm auriculosum, has been recorded in Australia. All seven species reach maturity in piscivorous birds. No intramolluscan developmental stages have yet been recorded. The metacercarial stage has only been described for two of the species: Diplostomum heronei Srivastava, 1954 (syn. D. Ketupanensis sensu Ganapati and Rao, 1962 nec Vidyarthi, 1937, according to Williams, 1967), and D. tregenna Nazmi, 1932. The metacercaria of $D$. heronei encysts in the musculature of freshwater fish in India; however, according to Khalil (1963), 
Two Strigeoid Trematodes in Gataxias auratus in Tasmania.

the metacercaria of $D$. tregenna remains unencysted in the brain of Clamas, a fish of the River Nile. The only other previous record of the metacercaria of a Diplostomum species encysting in fish is the metaccrcaria, Diptostomulum pigmentata Singh, 1956, which encysts in the muscles of freshwater cyprinoid fish in the Allahabad region of India, where

$D$. herone $i$ and $D$. ketupanensis Vidyarthi, 1937, have been recorded.

of the seven species previously assigned to the subgenus Dotichorehis, Diptostomum galaxiae n.sp. most closely resembles $D$. heronei and $D$. Ketupanensis in general morphology, distribution of vitellaria, shape and size of anterior testis and relative size of lappets. In all three species, vitellaria are extensively distributed in the posterior part of the forebody, extending anteriorly as far as the ventral sucker, whereas in $D$. marahoueense Baer, 1957, and D. auriculosum Dubois and Pearson, 1967, vitellaria are restricted in the forebody, to a narrow zone around the holdfast organ, and do not extend anteriorly as far as the ventral sucker. In $D$. butei $i$ Vidyarthi, 1937, and $D$. tregenna, vitellaria are distributed anteriorly well beyond the ventral sucker nearly to the pharynx. Dubois (1968), considers that $D$. duboisi Anantaraman and Balasubramaniam, 1953, is a synonym of $D$. butei and the present authors agree.

Diplostomm ketuoanensis Vidyarthi, 1937 is very similar in morphology to D. heronei, however, the body and organs of the former are about two to three times larger than those of the latter, and whereas uterine eggs are absent in the former, four or more eggs may occur in the uterus of the latter. Williams (1967), considered that D. ketupanensis sensu Ganapati and Rao, 1962, but not D. ketupanensis Vidyarthi, 1937, is a synonym of $D$. heronei, and the present authors concur. D. galaxiae n.sp. is significantly smaller than D. ketupanensis Vidyarthi, 1937, has a more elongate forebody, and contains up to 11 uterine eggs. The position of the anterior testis is variable in the former and sinistral in the latter.

D. heronei and D. galaxiae n.sp. are similar in size, however the former has a flat, round forebody, whereas that of D. gazaxiae n.sp. is elongate and very concave. The anterior testis of $D$. herone $i$ is dextral and the posterior testis is relatively longer than that of D. galaxiae n.sp. The excysted metacercariae of $D$. heronei is markedly smaller and has a relatively rounder forebody and larger hindbody than that of $D$. galaxiae $\mathrm{n}$. sp. The discovery of the intramolluscan developmental stages of these species would elucidate their relationship, however it is presently considered that differences in norphology of adults and metacercariae and the different intermediate and definitive hosts, warrant their specific separation.

A key to the species of the subgenus Dolichorchis is given below.

1a. Anterior testis L-shaped; extends width of hindbody.

Intestinal parasite of the Indian pariah kite, in S.E. India; and

Buteo rufinus mufinus, in N. India.

Syn.: Bolbophoms orientalis Vidyarthi, 1938

D. duboisi Anantaraman and Balasubramaniam, 1953

1b. Anterior testis not L-shaped; lateral in anterior hindbody ... D. buteit Vidyarthi, 1937

2a. Vitellaria not distributed anteriorly beyond ventral sucker $\ldots 2$

2b. Vitellaria distributed anteriorly beyond ventral sucker. Diplostomulum encysted in brain of freshwater fish in River Nile. Adult intestinal parasite of Egyptian kite, Cairo, Egypt

$$
\text { ....... D. tregenna Nazmi, } 1932
$$

3a. Vitellaria restricted to region of holdfast organ; anterior distribution distribution not reaching ventral sucker

3b. Vitellaria distributed widely in posterior forebody;

anterior distribution reaching ventral sucker

4a. Ventral sucker larger than oral sucker. Lappets projecting anterior to oral sucker.

Intestinal parasite of darter, in Queensland, Australia ......... D. auriculosum Dubois and Pearson, 1967

4b. Oral sucker larger than ventral sucker. Lappets not projecting anterior to oral sucker. 
S.J. Smith and J.L. Hickman

Parasite of upper small intestine of fishing owl, Ivory coast

\section{D. marahoueense Baer, 1957}

5a. Small flukes, body length less than $1.5 \mathrm{~mm}$

5b. Large flukes, body length more than $1.5 \mathrm{~mm}$.

Intestinal parasite of northern brown fishing ow1, in $\mathrm{N}$ India ....... Detupanensis Vidyarthi, 1937

6a. Forebody flat, round; anterior testis dextral.

Metacercaria encysts in muscles of freshwater fish, Andhra Pradesh.

Adult intestinal parasite of grey pond heron in N. and E. India ....... D. heronei Srivastava, 1954

Syn.: D. Ketupanensis sensu Ganapati and Rao, 1962

6b. Forebody elongate, \pm rectangular, concave; anterior testis variable (reproductive system amphitypic) .

Metacercaria encysts in muscles of freshwater fish, Lake Crescent.

Adult parasite in upper small intestine of white-faced heron,

Tasmania, Australia ........ D. galaxiae n.sp.

TABLE 6

NON-OVIGEROUS ADULTS OF DIPLOSTOMUM GALAXIAE n.sp.

Dimensions of mature (i.e. vitellaria producing phenolic egg-she11 precursors), non-ovigerous adults of 'sinistral' and 'dextral' types, from the white-faced heron.

Sample size

Body length

Forebody: depth

length (FBL)

width

Hindbody: depth

length (HBL)

width

Oral sucker:depth

length

width

Ventra1 sucker:depth

length

Pharynx: length width

width

Left lappet: length

$$
\text { width }
$$

Right lappet: length

$$
\text { width }
$$

Holdfast organ:depth length width

Ovary:depth

length

width

Anterior testis:depth

$$
\text { length }
$$

Posterior testis:

left lobe depth

$$
\text { length }
$$

width

right lobe depth

$$
\text { length }
$$

\begin{tabular}{|c|c|}
\hline 889 & $(771-1058)$ \\
\hline 106 & $(91-121)$ \\
\hline 496 & $(423-635)$ \\
\hline 351 & $(318-408)$ \\
\hline 234 & $(227-257)$ \\
\hline 396 & $(333-484)$ \\
\hline 292 & $(272-333)$ \\
\hline 60 & $(49-76)$ \\
\hline 63 & $(49-68)$ \\
\hline 70 & $(61-76)$ \\
\hline 61 & - \\
\hline 62 & $(53-68)$ \\
\hline 76 & $(68-84)$ \\
\hline 51 & $(42-57)$ \\
\hline 38 & $(30-46)$ \\
\hline 81 & $(72-99)$ \\
\hline 40 & $(30-53)$ \\
\hline 80 & $(68-95)$ \\
\hline 41 & $(30-57)$ \\
\hline 75 & $(68-84)$ \\
\hline 125 & $(114-133)$ \\
\hline 137 & $(129-148)$ \\
\hline 76 & - \\
\hline 76 & $(68-91)$ \\
\hline 89 & $(76-106)$ \\
\hline 148 & - \\
\hline 100 & $(80-114)$ \\
\hline 117 & $(95-171)$ \\
\hline 122 & - \\
\hline 162 & $(148-190)$ \\
\hline 106 & $(95-118)$ \\
\hline 109 & $(95-114)$ \\
\hline 164 & $(129-190)$ \\
\hline 101 & $(87-118)$ \\
\hline & 0.96 \\
\hline & 1.25 \\
\hline
\end{tabular}$$
\text { width }
$$

O.S. $(1+w) /$ V.S. $(1+w)$

FBL/HBL
'Dextral' $\mathrm{n}=14$

$983(847-1210)$

$132(121-151)$

$581(469-711)$

$363(302-408)$

$259(242-272)$

$429(348-544)$

$292(272-318)$

$66(57-70)$

$65(49-72)$

$67(61-70)$

$70(65-76)$

$63(57-72)$

$72(61-84)$

53 -

$35(32-38)$

$84(72-91)$

$39(34-46)$

$81(76-87)$

$39(30-46)$

$81(68-91)$

$138(1.14-167)$

$130(114-156)$

$66(65-68)$

$82(80-84)$

$103(91-114)$

$109(95-118)$

108 (103-114)

$115(95-137)$

$163(137-190)$

103 -

$108(99-114)$

126 (103-152)

99

0.98

1.35 
Biology

Three out of six ducklings fed cysts of D. gataxiae n.sp. from Galaxias auratus becane infected. Each infected bird, however, harboured only one fluke. The average infectivity rate of metacercariae in these ducklings was about 1 in 100 . Although ducklings are not very susceptible hosts for $D$. galaxiae n.sp., two flukes did grow to maturity. Excysted metacercariae are about half adult size, and genital primordia are discernible in the relatively short, stumpy hindbody. As growth occurs, the reproductive system develops and the hindbody increases in size relative to the forebody. One small, immature fluke was found in S7, 10 hours after infection of a duckling (fig. 5). After 4,3 days, one specimen was living in S1, and had grown to adult size and form. It was sexually mature, with vitellaria producing phenolic egg-shell precursors. Sperm filled the seminal vesicle, but no uterine eggs were present. After 12,4 days, one specimen was living in Sl, and contained one uterine egg.

The distribution of adults in two white-faced herons killed while feeding on galaxiids at Lake Crescent, is shown in figure 5. They occurred from Sl to S6, but were concentrated in $\mathrm{S} 2$ and $\mathrm{S} 3$.

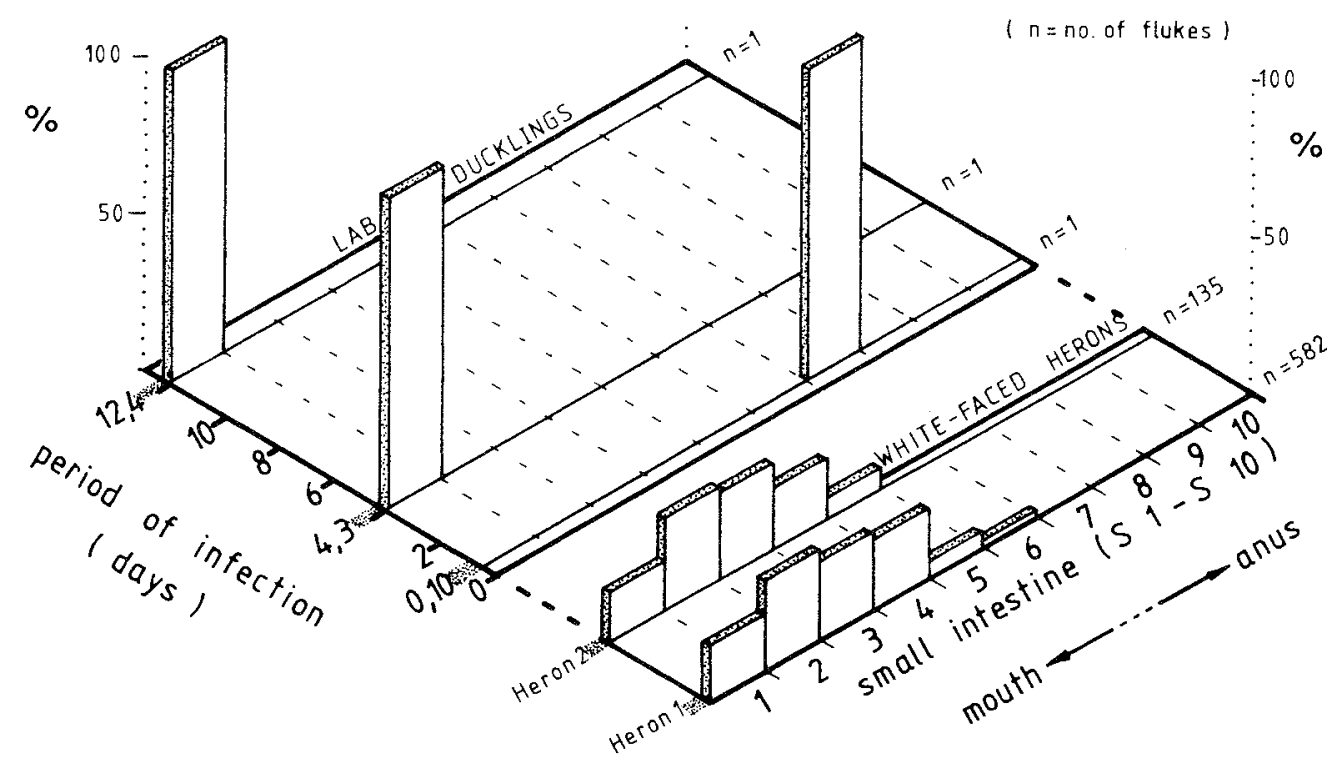

FIG. 5 - Diplostomum galaxiae n.sp. Distribution in digestive tracts of laboratory ducklings, and wild, white-faced herons.

\section{EGG (fig. 4)}

The broadly oval egg has a small round operculum and is densely packed with granular vitelline cells. The egg-shell is relatively thin, clear when formed, but becomes tanned yellow. A clear sphere about 24 m diameter, underlies the operculum. The dimensions of live eggs taken from the lumen of the upper small intestine of infected herons, and dimensions of fixed uterine eggs of 'sinistral' and 'dextral' adults from the same hosts are shown in table 7 . 
S.J. Smith and J.L. Hickman

TABLE 7

DIMENSIONS OF EGGS OF DIPLOSTOMUM GALAXIAE n.sp.

Dimensions of live and fixed eggs produced by adults in naturally infected white-faced herons.

\begin{tabular}{llcll}
\multicolumn{1}{c}{ Type } & $\begin{array}{c}\text { Live/ } \\
\text { fixed }\end{array}$ & $\begin{array}{c}\text { Number } \\
\text { of } \\
\text { eggs }\end{array}$ & Length & Width \\
Mixed & live & 15 & $95(89-101)$ & $65(63-67)$ \\
'Sinistral' & fixed & 10 & $98(91-103)$ & $59(53-65)$ \\
'Dextral' & fixed & 12 & $97(87-99)$ & $60(53-65)$
\end{tabular}

\section{METACERCARIA}

Metacercarial cyst (fig. 6)

The entire black cyst is composed of a thin, but resilient, transparent inner layer of parasite origin, and a thick opaque cellular outer layer of host origin. The 'inner cyst', which separates readily from the 'outer cyst', is oval. It encloses a curled metacercaria, partially surrounded by densely packed coarse lipid droplets. The outermost layer of the 'outer cyst', or host reaction coat, consists of black pigmented melanocytes, which make even deep-seated cysts conspicuous in the translucent body of Galaxias auratus. Cysts are distributed widely in the musculature of the body and head, causing 'black spot' or 'black grub' disease. The dimensions of the cyst are shown in table 8 .

TABLE 8

CYSTS OF DIPLOSTOMUM GALAXIAE n.sp.

Dimensions of live metacercarial cysts, dissected from naturally infected Galaxias auratus.

Number

10

10
Length

$$
1125(1043-1210)
$$$$
629(575-643)
$$

Width

$866(771-937)$

$354 \quad(333-386)$

External dimensions 'inner cyst'

All of fourteen fish collected in June 1978 and June 1979, from the Clyde River where it enters Lake Crescent, were infected with Diplostomum galaxiae n.sp. The average number of cysts per fish was $42.7(10-104)$, and the average size of the fish was $6.4(4.8-9.9) \mathrm{cm}$.

Excysted metacercaria (fig. 6)

The size and development of excysted metacercariae varies greatly (table 9). The forebody is relatively large and elongate and the hindbody, a rudimentary stump. Gonadal primordia are visible in advanced metacercariae, and 'dextral' and 'sinistral' types are often discernible. When 39 metacercariae, dissected from fish collected in June 1979, were excysted, $51 \%$ were mature enough to distinguish the position of the anterior testis; $55 \%$ of these were 'dextral' and $45 \%$ 'sinistral'. In advanced metacercariae, the oral sucker, pharynx and caeca are formed, lappets and holdfast organs are well-developed and the bilobed gland at the base of the holdfast organ is conspicuous. The forebody tegument is spinous, spines diminishing in size posteriorly, and the hindbody tegument is aspinous. Large paranephridial canals, through which body fluids and small lipid droplets move, anastomose throughout the body. The genital pore is slightly dorsal to the terminal excretory pore. 


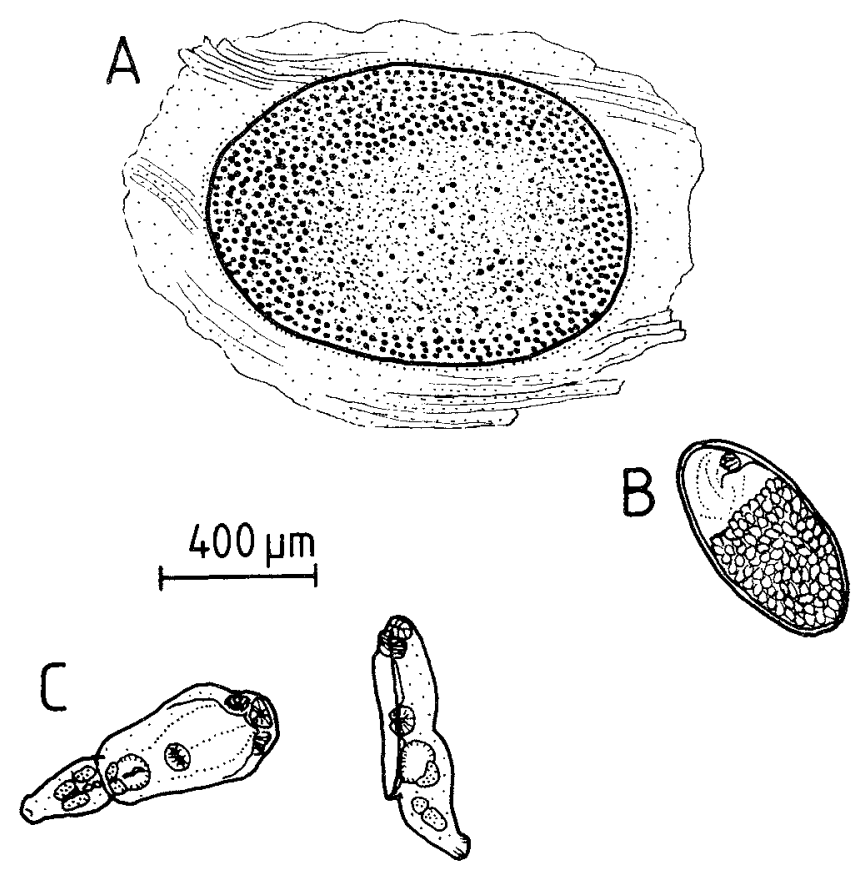

FIG. 6 - Diplostomum galaxiae n.sp. A: black metacercarial cyst embedded in muscle of fish host. B: oval 'inner cyst' removed from thick cellular 'outer cyst'. $\mathrm{C}$ : excysted metacercariae after 3 hours at $41^{\circ} \mathrm{C}$. (A, B and $\mathrm{C}$ are drawn to same scale.)

\section{DISCUSSION}

Neither of the two strigeoid species encysting in Galaxias auratus at Lake Crescent, has previously been recorded in Australia. Apatemon (Apatemon) gracilis and Diplostomum (Dolichorchis) galaxiae n.sp. encyst in different tissues of the fish host and infect different definitive hosts. Domestic ducklings are much more susceptible to experimental infection by $A$. gracizis than by $D$. galaxiae n.sp. - not surprisingly considering that anatids are the main definitive hosts for $A$. gracilis around the world, whereas there are no previous records of a species in the subgenus Dolichorchis infecting an anatid. A black duck, Anas superciziosa, shot at Calverts Lagoon $100 \mathrm{~km}$ from Lake Crescent, was found to harbour $A$. gracilis, but not $D$. galaxice n.sp., and two white-faced herons, shot at Lake Crescent, harboured only D. galaxiae n.sp., despite the fact that about $70 \%$ of the fish being eaten by the herons contained cysts of A. gracilis.

The cercariae and metacercariae of $A$. gracilis are known to occur in Iceland and Scotland (Blair 1976), Wales (Crocombe 1959), central Europe (Vojtek 1964), Japan (Yamaguti 1933), and North America (Hoffinan 1959, Lester 1974). The genera Ancylastrum and Lymnaea serve as molluscan hosts and the fish intermediate hosts include members of the families Cobitidae, Cottidae, Eleotridae, Gasterosteidae, Gobiidae and Salmonidae. Cysts from these fish intermediate hosts are very similar in morphology, but vary in size. The sizes of cysts from fish in Tasmania, the U.S.A. and Scotland, were shown in table 4. The external cyst dimensions vary much more between host species than do the internal cyst dimensions. Cyst wall thickness is apparently related to the identity of the fish host. 
5.J. Smith and J.L. Hickman

TABLE: 9

EXCYSTED METACERCARIAE OF DIPLOSTOMUM GALAXIAE n.sp.

Dimensions of metacercariae excysted in vitro after 3 hours at $41^{\circ} \mathrm{C}$ : (a) too immature to distinguish anterior testis, (b) 'sinistral' type, (c) 'dextral' type.

(a) $\mathrm{n}=11$

Body length

Forebody: Iength

width

Hindbody: length width

Ora1 sucker: length width

Ventral sucker:length width

Pharynx: 1ength width

Left lappet: length width

Right 1appet:1 ength width

Holdfast organ: length width

Ovary: length width

Anterior testis: length width

Posterior testis:

left lobe length width

right lobe length width

O.S. $(1+w) /$ V.S.$(1+w)$

$\mathrm{FBL} / \mathrm{HBL}$

$\begin{aligned} 401 & (355-461) \\ 319 & (287-363) \\ 176 & (156-228) \\ 82 & (68-98) \\ 68 & (57-72) \\ 46 & (40-49) \\ 45 & (42-46) \\ 40 & (38-46) \\ 44 & (42-48) \\ 29 & (25-34) \\ 21 & (19-23) \\ 49 & (46-49) \\ 31 & (27-34) \\ 46 & (42-49) \\ 30 & (27-34) \\ 69 & (68-72) \\ 74 & (53-76) \\ - & \\ - & \\ - & \\ - & \\ - & \\ - & \\ - & \\ - & \\ & \\ & \\ & \end{aligned}$

(b) $n=7$

(c) $\mathrm{n}=13$

$\begin{aligned} 691 & (582-816) \\ 513 & (438-605) \\ 213 & (194-232) \\ 183 & (144-227) \\ 123 & (106-137) \\ 54 & (51-57) \\ 49 & (46-53) \\ 42 & (38-46) \\ 47 & (42-51) \\ 33 & (30-40) \\ 25 & (23-29) \\ 70 & (61-72) \\ 38 & (34-42) \\ 69 & (57-76) \\ 38 & (30-44) \\ 104 & (99-114) \\ 81 & (76-87) \\ 22 & (19-23) \\ 24 & (23-25) \\ 38 & (34-46) \\ 30 & (23-38) \\ & \\ 41 & (34-49) \\ 27 & (23-30) \\ 42 & (34-49) \\ 7-30) & \\ & 1.16 \\ & 2.80\end{aligned}$

$665(575-756)$

$479(393-559)$

$218(194-247)$

$186(151-204)$

$123(114-148)$

$55(46-61)$

$52(42-65)$

$45(38-51)$

$52(42-63)$

$36(30-42)$

$25(23-29)$

$70(61-72)$

$41(36-42)$

$71 \quad(61-80)$

$43(34-61)$

$107(91-114)$

$81(72-91)$

$27-$

$23-$

$39(34-46)$

$34(27-42)$

$47(38-53)$

$29(23-34)$

$43(34-49)$

$31(27-38)$

1.10

2.58

The molluscan hosts of the strigeoid species at Lake Crescent are not known, however Potomopyrgus spp. (Timms 1978), Physastra gibbosa and Rivisessor gumi inhabit the 1 ake. At Calverts Lagoon in southeast Tasmania trenatode developmental stages conforming to those of A. gracilis (Blair 1976) were found in Coxiella badgerensis on one occasion (Smith 1981).

The discovery of A. gracilis and D. galaxiae n.sp. in Tasmania may be cause for concern for local trout fishing and trout farming interests. The specificity of D. galaxiae $\mathrm{n} . \mathrm{sp}$. at the secondary intermediate host level is unknown, however A. gracizis infects rainbow and brown trout in Scotland. These fish are widespread and important in Tasmania. In Scotland, experimentally infected trout of both species were found to have cysts of A. gracilis concentrated around the head with a small percentage occurring in the eye (Blair 1976). Further studies are needed to determine the extent of these parasites in Tasmania and whether their intermediate host ranges extend to introduced fish species.

\section{ACKNOWLEDGMENTS}

This rescarch was conducted while one of us (S.J.S.) held an Australian Government Postgraduate Research Award at the University of Tasmania for Ph.D. study. We are grateful for assistance given to us by various members of the Zoology Department, University of Tasmania, particularly Dr Rob White, Ron Mawbey and Jerry Lim; the Inland Fisheries Commission; and the Tasmanian Museum and Art Gallery. 


\section{REFERENCES}

Anantaraman, M. \& Balasubramaniam, G., 1953: A strigeid, Diplostomum duboisi n.sp., from the Indian kite irilvus migrons govinda sykes. The Indian Veter. Joum., 29: 465-469.

Baer, J.G., 1957: Trématodes et cestodes récoltés en Côte d'Ivoire, avec remarques sur la famille des Dicrocoeliidae Odhner et sur les parasites des Damans. Rev. Buisse 4002 . $64: 547-575$.

Berra, T.M. \& All, R.J., 1978: Incidence of black spot disease in fishes in Cedar Fork Creek, Ohio. Ohio d. Sci., 78(6): 318-322.

Beverley-Burton, M., 1961: studies on the trematoda of British freshwater birds. Proc. 2002. Soc. Lond., 137: 13-40.

Blair, D., 1976: Observations on the life-cycle of the strigeoid trematode Apatemon (Apatemon) gracilis (Rudolphi, 1819) Szidat, 1928. J. Helminth., 50: 125-131.

Crocombe, J., 1959: A SURVEY OF THE PARASITES OF CERTAIN FRESHWATER FISH IN GLAMORGAN (WALES) AND SOME NOTES ON THE LIFE-HISTORY OF APATEMON GRACILIS PELLUCIDUS. UnPub, M.Sc. thesis, University of wales. (cited by Blair 1976)

Dubois, G., 1937: Etude de quelques Strigéidés d'Australie et notes sur le genre Fibricola Dubois, 1932. Ann. Parasitol. Paris, 15: 231-247 and 333-353.

- 1951: Etude des trématodes nord-americains de la collection E.L. Schiller et revision du genre Motocotylus Diesling 1839. Bull. Soc. neuchâtel. Sei. nat., 74 : $41-76$.

1953: Systêmatique des strigeida. Complément de la Monographie. Mém. Soc. neuchâtel. Soi. nat., 8(2): 1-141.

- 1961: Le genre Diplostomum von Nordmann, 1832, (Trematoda Strigeida). Bul2. Soc. neuchâtel. Sci. nat., 84: 113-124.

, 1968: Synopsis des Strigeidae et des Diplostomatidae (Trematoda). Mém. Soc. neuchâtel. Sci. nat., 10: 1-258.

\& Angel, L.M., 1972: Strigeata (Trematoda) of Australian birds and mammals from the helminthological collection of the University of Adelaide. Trons. R. Soc. S. Aust., 96: 197-21.5.

\& Pearson, J.C., 1965: Quelques Strigeida (Trematoda) d'Australie. Bull. Soc. neuchâtez. Sci. nat., 88: 77-99. , 1967: Quelques Strigeida (Trematoda) d'Australie. Bull. Soc. neuchâtel. Sci. nat., 90: 185-204.

Ganapati, P.N. \& Rao, K.H.C., 1962: Ecological and life-history studies on a strigeid metacercaria (Trematoda: Diplostomatidae) from freshwater fishes of Andhra Pradesh. Parasitology, 52: 519-525.

Hoffman, G.L., 1959: Studies on the life cycle of Apatemon gracilis pellucidus (Yamag.) (Trematoda: Strigeoidae). Trans. Amer. Fisheries Soc., 88: 96-99.

, 1967: PARASITES OF NORTH AMERICAN FRESHWATER FISHES. Univ. California Press, Berkeley. (cited by Berra \& Au 1978)

Johnston, S.J., 1904: Contributions to a knowledge of Australian Entozoa. III. On some species of Holostomidae from Australian birds. Proc. Linn. Soc. N.S.W., 29: 108-116.

Johnston, T.H. \& Angel, L.M., 1951: The morphology and life cycle of the trematode, Apatemon intermedius, from the black swan. Trans. R. Soc. S. Aust., 74:66-78.

\& Cleland, E.R., 1938: Larval trematodes from Australian terrestrial and freshwater molluscs. Part IV. Cercapia (Furcocercaria) murrayensis n.sp. Trans. R. Soc. S. Aust., 62: 127-131.

Khalil, L.F., 1963: On DiplostomuZum tregenna, the diplostomulum stage of Diplostomum tregenna Nazmi Gohar, 1932 with an experimental demonstration of part of the life cycle. J. Helminth., 37: 199-206.

Lester, R.J.G., 1974: Parasites of Gasterosteus aculeatus near vancouver, British Columbia. Columbia. Syesis, 7: 195-200.

Mitchell, J.S., Halton, D.W. \& Smyth, J.D., 1978: Observations on the in vitro culture of Cotylurus erraticus (Trematoda: Strigeidae). Int. J. Parasitol., 8: 389-397.

Nazmi, M., 1932: Diplostomum tregenna sp.n., a new trematode of the Egyptian kite. Ann. Mag. Nat. Hist., 9: 567-573.

Ricci, M. \& Carrescia, P.M., 196l: Contributo alla conoscenza dell'elmintofauna degli uccelli d'acqua dolce in Italia. I. Trematoda. Riv. Parassit., 22: 237-258.

Rudolphi, C.A., 1819: Entozoorum synopsis cui accedunt mantissa duplex et indices Locupletissimi. Berol.: 1-81l. (cited by Yamaguti 1971) 
S.J. Smith and J.L. Hickman

Singh, R.N., 1956: Studies on a new strigeid metacercaria parasitic in cyprinoid fishes. Proc. Nat. Acad. Sci. India, 26: 255-263.

Smith, S.J., 1981: THE TREMATODE FAUNA OF A BRACKISH COASTAL LAGOON IN TASMANIA. Unpub. Ph.D. thesis, University of Tasmania.

Srivastava, U.S., 1954: On a new strigeid trematode of the genus Diplostomm v. Nordmanr, 1832 from the common grey pond heron. Indian J. Helminth., 6: 7-12.

Szidat, L., 1928: Zur Revision der Trematodengattung Strigea Abildgaard. Centrazbz. f. Bakt. I. Abt. Oriq., 105: 204-215. (cited by Yamaguti 1971)

Timms, B.V., 1978: The benthos of seven lakes in Tasmania. Arch. Hydrobioz., 81: 422-444. Vidyarthi, R.D., 1937: Studies on the family Diplostomidae, Poirier. Part I -.. Two new parasites of the genus Diplostomm $v$. Nordmann from Indian carnivorous birds. Proc. Nat. Acad. Sei. India, 7: 1-64.

- 1938: Avian trematodes of the genera Neodiplostomoides nov.gen., Bolbophorus Dubois, 1934, and GLossodiplostomum Dubois, 1932. Parasitology, 30: $33-39$.

Vojtek, J., 1964: Zur Kenttnis des Entwicklungszyklus von Apatemon cobitidis (Linstow, 1890). Z. Parasitenk., 24: $578-599$.

Williams, H.O., 1967: Studies on the adult and diplostomulum of Diplostomum (Dolichorchis) Zeonensis (Strigeida: Trematoda). Parasitology, 57: 673-681.

Yamaguti, S., 1933: Studies on the helminth fauna of Japan. Part I. Trematodes of birds, reptiles and mammals. Jap. J. Zoot., 5: 1-134.

- 1971: SYNOPSIS OF DIGENETIC TREMATODES OF VERTEBRATES. Volumes I and II. Keigaku, Tokyo. 